\title{
PHYLLANTHUS BALGOOYI (EUPHORBIACEAE S.L.), A NEW NICKEL-HYPERACCUMULATING SPECIES FROM PALAWAN AND SABAH
}

\author{
PETRA HOFFMANN ${ }^{1}$, ALAN J.M. BAKER ${ }^{2}$, DOMINGO A. MADULID ${ }^{3}$ \\ \& JOHN PROCTOR 4
}

\begin{abstract}
SUMMARY
Phyllanthus balgooyi Petra Hoffm. \& A.J.M. Baker (Euphorbiaceae s.l.or Phyllanthaceae) is described from Palawan (Philippines) and Sabah (Malaysian Borneo) as a species of Phyllanthus sect. Emblicastrum. The species is restricted to ultramafic sites and easily identified by its unusual leaf venation and its jade-green sap. It is the second most visibly nickel-accumulating plant known to date.
\end{abstract}

Key words: Euphorbiaceae, Phyllanthus, Borneo, Philippines, nickel-hyperaccumulation.

\section{INTRODUCTION}

In the course of studies of ultramafic vegetation in the Philippines (Baker et al., 1992; Proctor et al., 1997, 2000a, b) it was noted that several collections identified as Phyllanthus lamprophyllus Müll.Arg. differed markedly from material collected on non-ultramafic sites and other ultramafic sites in the Malay Archipelago, which all had low nickel concentrations. Leaf dry matter nickel concentrations in excess of $1.6 \%$ were subsequently measured in these plants, confirming a strong nickel hyperaccumulator status. When the stem or main root is slashed this Phyllanthus exudes a jade-green sap as a consequence of the extremely high Ni concentrations in the phloem tissues, which contain $9 \%$ nickel on a dry weight basis. The only other instance of a plant with such a visibly apparent nickel accumulation in an exudate is the New Caledonian tree Sebertia acuminata (Sapotaceae), where the blue latex contains $25 \%$ nickel (Jaffré et al., 1976).

The hyperaccumulating Phyllanthus specimens display a number of morphological differences to $P$. lamprophyllus. Therefore, the new species $P$. balgooyi is described here. Phyllanthus balgooyi occurs in ultramafic sites in Palawan (Philippines) and Sabah (Malaysian Borneo). At least 17 specimens of this new species have been collected and deposited in the herbaria of Kew and Leiden alone since 1947. The earliest specimen known to us, however, was collected in 1886 by Vidal in Palawan. All of these were previously filed under P. lamprophyllus, or occasionally under P. buxifolius (Blume) Müll.Arg.

1) The Herbarium, Royal Botanic Gardens, Kew, Richmond, Surrey, TW9 3AB, United Kingdom.

2) School of Botany, The University of Melbourne, VIC 3010, Australia.

3) Botany Division, National Museum, Manila, The Philippines.

4) Department of Biological Sciences, University of Stirling, Stirling, FK9 4LA, United Kingdom. 
Phyllanthus lamprophyllus is the type of the initially monotypic section Emblicastrum first described by Müller (1866: 324) from Java. The species also occurs in Sulawesi, the Lesser Sunda Islands and the Moluccas (Airy Shaw, 1982: 32), The Philippines (Airy Shaw, 1983: 41), New Guinea (Airy Shaw, 1980a: 189) and Australia (Airy Shaw, 1980b: 666). The New Guinean and Australian specimens were first described as P. hellwigii Warb. Webster \& Airy Shaw (1971: 109) noted that the Philippine material of P. lamprophyllus should be referred to this species. Later (Airy Shaw, 1976: 361), the floral characters of sect. Emblicastrum Müll.Arg. that had been obscured by a rare mistake in Müller (1866) were clarified, and $P$. hellwigii was synonymized with P. lamprophyllus.

In his enumeration of Philippine Euphorbiaceae, Airy Shaw (1983) listed three specimens of the true P. lamprophyllus but did not remark on aberrant specimens from ultramafic sites. He had, however, wrapped the specimen $P N H$ (Edaño) 178 which had been identified as 'Phyllanthus palawanensis Merr. \& Quisumb., n.sp.' in a type folder at Kew, and noted on the Leiden duplicate that he considered it to be a separate species. Phyllanthus palawanensis has never been validly described. We are designating this Kew specimen as the holotype of our new species, but feel that the epithet suggested by Merrill does not reflect the true distribution of the taxon. Therefore, we name it after the eminent Malesian botanist M.M.J. van Balgooy.

We have been unable to find a Phyllanthus in the Malay Archipelago that resembles our new species more than P. lamprophyllus. Phyllanthus curranii C.B. Rob. from the Philippines (Luzon) is very similar to P. lamprophyllus, and may be conspecific. Robinson (1909: 77) placed it in section Emblicastrum with P. lamprophyllus, but did not discuss the differences that led him to distinguish a new species. Phyllanthus curranii agrees in all points listed below with P. lamprophyllus. As far as can be ascertained from the collections held at the Kew Herbarium, it seems to differ in the slightly smaller leaves and longer pistillate pedicels.

Another very similar plant is Phyllanthus robinsonii Merr., known only from the type specimen from Cebu (Philippines). Merrill (1912: 405) placed it in section Emblicastrum with a question mark because the type bears only pistillate flowers. Distinguishing infrageneric characters of the staminate flowers remain unknown. Phyllanthus robinsonii was described as a separate taxon on account of its indistinct secondary leaf venation. Otherwise, the type BS (Ramos) 11058 at Kew is very similar to P. lamprophyllus and P. curranii.

The main characters of the monoecious section Emblicastrum are staminate flowers with four sepals and discrete disc segments, two connate stamens with horizontally dehiscing anthers, and pistillate flowers with entire, more or less connate styles. Section Emblicastrum was placed in subgenus Eriococcus (Hassk.) Croiz. \& Metc. by Webster (1957: 359) who suspected that the then monospecific sections Emblicastrum, Eriococcodes Müll.Arg. and Scepasma (Blume) Müll.Arg. "represent merely individual species with striking 'key' characters; a recasting of subg. Eriococcus along phylogenetic lines may result in radical changes in the circumscription of the constituent taxa".

The clear physiological difference between $P$. balgooyi and P. lamprophyllus is visually expressed in the green exudate from the stem and root of the former species. A much more accessible character in which the new species differs from P. lamprophyllus is its conspicuous leaf venation (Fig. 1a). This type of venation seems to be 
unique among the Phyllanthus species in the Malay Archipelago, and resembles that of species of the Chamaecrista mimosoides (L.) Greene-group in the Leguminosae. In contrast, $P$. lamprophyllus has often indistinct, numerous (8-12) pairs of secondary veins that are much thinner and shorter than the midvein, branch off evenly over the length of the leaf, and run straight to the midvein in an angle of c. $45^{\circ}$ (Fig. $1 \mathrm{~m}$ ).

Phyllanthus lamprophyllus differs furthermore from P. balgooyi in having strongly overlapping sepals (including the bases) in both sexes, slightly shorter (up to $1.5 \mathrm{~mm}$ long) and obconical staminate pedicels (up to $1.5 \mathrm{~mm}$ long), a shorter androecium (0.5-1 $\mathrm{mm}$ long) and free anthers, as well as in its complete lack of papillae in the pistillate flowers, a copious pistillate disc which is annular to irregularly dissected, and a much longer style (1.5-2 $\mathrm{mm}$ long in flower, c. $2.5 \mathrm{~mm}$ long in fruit) that extends beyond the sepals in most mature flowers (Fig. 11). The leaf venation and the shape and length of the style alone are sufficient to safely distinguish the two species with the naked eye.

\title{
Phyllanthus balgooyi Petra Hoffm. \& A.J.M. Baker, spec.nov. - Fig. 1a-k, Map 1
}

\begin{abstract}
Species nova sectionis Emblicastri in subgenere Eriococco, P. lamprophyllo simillima sed succo conspicue viride, venis lateralibus foliorum crassis utrinque 1-2 subparallelis atque in tertio vel dimidio basali ortis, sepalis basim valvatis vel vix imbricatis, pedicellis masculis longioribus (1.7-3 mm nec usque $1.5 \mathrm{~mm}$ longis) teretibus, androecio longiore (c. $1.5 \mathrm{~mm}$ nec usque $1 \mathrm{~mm}$ longo), antheris connatis, floribus femineis papillas conspicuas abundantes intus ferentibus, partibus disci feminei minutis discretis, stylo breviore $(0.4-0.8 \mathrm{~mm}$ nec 1.5-2.5 mm longo) sepala non excedenti differt. - Typus: PNH (Edaño) 178 (holo K; iso L), Philippines, Palawan, Bacuñgan, Puerto Princesa, 23 March 1947.
\end{abstract}

Monoecious shrubs or small trees, 0.5-8 m high (tallest in Sabah), bole up to $2.1 \mathrm{~m}$ high, diameter up to $25 \mathrm{~cm}$, branching phyllanthoid; cataphylls roughly triangular, acute, peltate, c. 3 by $2 \mathrm{~mm}$, with wide hyaline, erose margin; plagiotropic branchlets 4-12 per internode, simple, (3-)5-17 cm long; axis scabrous, the papillae similar to those covering the abaxial surfaces of the sepals and the style, glabrescent. Bark rough, longitudinally fissured, greyish brown; inner bark exuding abundant clear, brightly jadegreen sap. Stipules roughly triangular, acute, peltate, $1.5-2$ by $0.7-1 \mathrm{~mm}$, with wide hyaline, erose margin. Leaves closely distichous, sessile, 20-70 per branchlet, 0.7-1.5 by $0.3-0.6 \mathrm{~cm}$, asymmetrical, basally convex-acute in the proximal leaf-half, acute to rounded in the distal leaf-half, apically obtuse, mucronulate, coriaceous, glabrous, shiny; midvein asymmetrical; secondary veins 1 or 2 per leaf half, nearly as thick as the midvein, all arising in the basal third to half, and running nearly parallel to the midvein to the apical third; higher venation reticulate and relatively indistinct, especially abaxially. Flowers in pairs in leaf axils on distal half of plagiotropic branchlets, staminate and pistillate flowers on the same branchlet; bracts $0.7-1$ by $0.5-0.7 \mathrm{~mm}$, triangular to ovate, lacerate, hyaline, glabrous. Staminate flowers $2-3$ by c. $2 \mathrm{~mm}$; pedicels $1.7-3$ $\mathrm{mm}$ long, terete; sepals 4 , imbricate but not overlapping at the base, biseriate, $2-3$ by c. $1 \mathrm{~mm}$, the outer two slightly shorter and wider than the inner two, oblong to slightly ovate, apically rounded, adaxially keeled, entire, smooth and glabrous on both sides; disc glands 4, discrete, alternisepalous, roughly orbicular with a sunken centre, $0.2-0.3$ by $0.2-0.3 \mathrm{~mm}$, glabrous; stamens 2 , completely connate including the anthers, c. 1.5 long; the fused filaments $0.2-0.4 \mathrm{~mm}$ wide; the fused anthers c. $0.4 \mathrm{~mm}$ wide, dehiscing horizontally. Pistillate flowers $1.5-2$ by $1.5-2 \mathrm{~mm}$; pedicels $0(-0.3 \mathrm{~mm}$ long); 


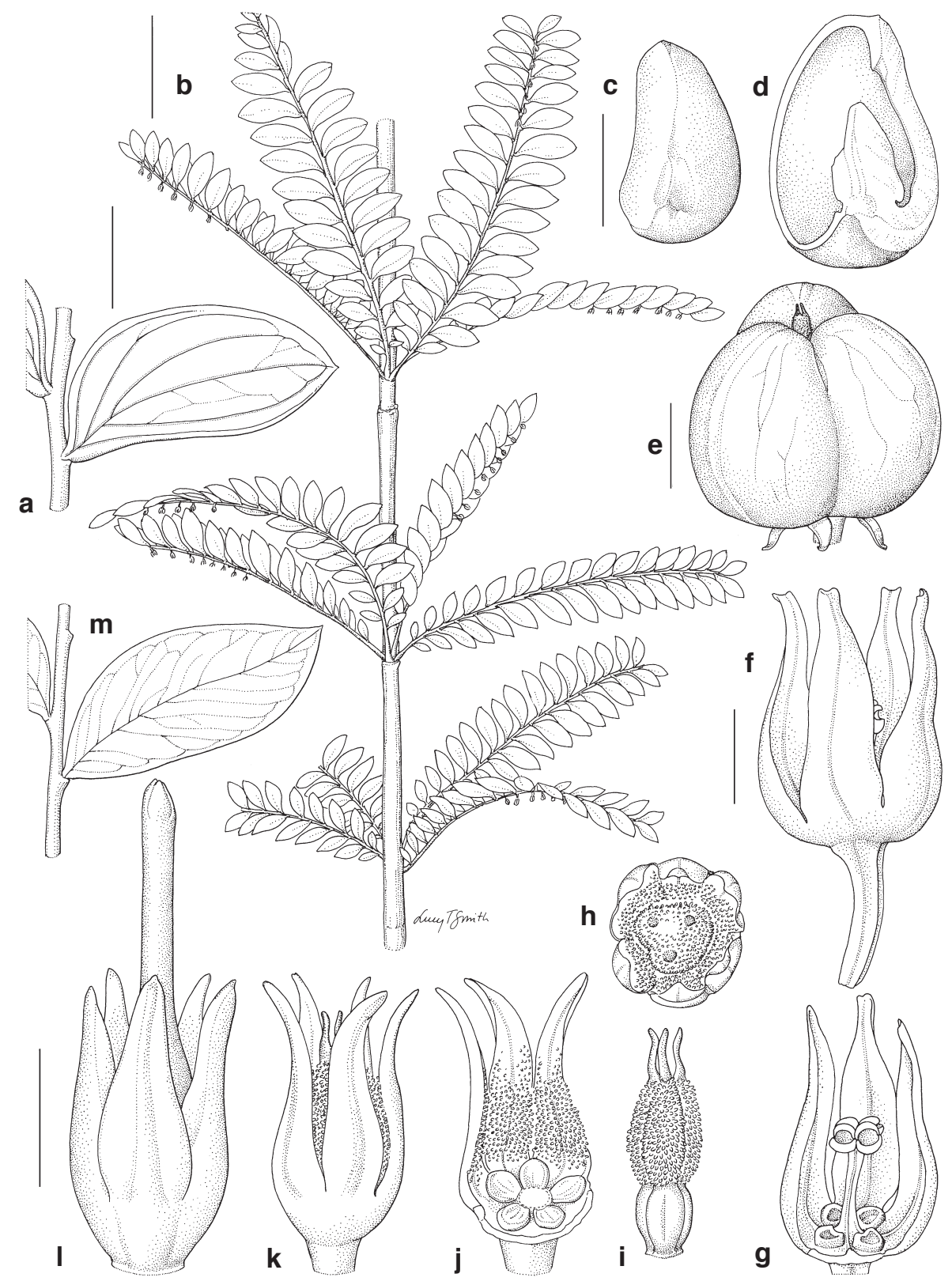

Fig. 1. a-k: Phyllanthus balgooyi Petra Hoffm. \& A.J.M. Baker. a. Leaf; b. habit; c. seed, ventral view; d. valve; e. fruit; f. staminate flower; g. staminate flower, one sepal removed; h. young pistillate flower seen from above; i. gynoecium; j. mature pistillate flower, two sepals and gynoecium removed; k. pistillate flower. - 1, m: P. lamprophyllus Müll.Arg. l. Pistillate flower; $\mathrm{m}$. leaf (a, b: PNH (Edaño) 178 (K); c-e: SAN (Madani) 89396 (K); f, g, i-k: SAN (Shea \& Ranau) 77278 (K); h: Ridsdale SMHI 1584 (K); 1-m: Hasskarl 3966 (L, holotype)). - Scale bars: $\mathrm{a}, \mathrm{m}=5 \mathrm{~mm}, \mathrm{~b}=2 \mathrm{~cm}, \mathrm{c}-\mathrm{e}=2 \mathrm{~mm}$, $\mathrm{f}-1=1 \mathrm{~mm}$. Drawing by Lucy T. Smith. 
sepals 5 or 6 , not or only slightly overlapping at the base, $1.5-2$ by $0.5-0.7 \mathrm{~mm}$, of roughly equal size, oblong to slightly ovate, apically rounded and very slightly cucullate, entire, abaxially glabrous, adaxially densely covered with papillae except towards the apex, persistent, at anthesis closed around the style with only the tips spreading giving the flower an urceolate appearance, presenting a small but highly papillose surface to pollinators, sometimes more loosely spreading; papillae about twice as long as wide, individually visible under dissecting microscope at medium magnification; disc glands 5 or 6 , persistent, discrete, alternisepalous, roughly orbicular, $0.1-0.3$ by $0.1-0.3 \mathrm{~mm}$, glabrous; gynoecium $1-1.3$ by $0.3-0.5 \mathrm{~mm}$, shorter than or of equal length as the sepals; ovary 3-carpellate, glabrous, ellipsoidal, longitudinally 6-ridged due to the abaxially prominent midribs of the tightly adjacent sepals in bud; ovules 2 per locule, hemitropous (funicle attachment about halfway between micropyle and chalaza); obturators very small, one per ovule; styles entire, basally connate into a column of $0.3-0.5$ by c. $0.3 \mathrm{~mm}$, free for c. $1 / 2$ of their lengths, erect, densely covered in papillae (like sepals adaxially); stigmas $3,0.1-0.3$ by c. $0.1 \mathrm{~mm}$, apically inflexed, acute to obtuse, sometimes apically emarginate, or crenulate at the margin, glabrous, dark, shiny. Fruits capsular, 3-lobed, dehiscing septicidally (from the base), loculicidally (from the apex) and septifragally (membranaceous central area of septum tearing irregularly), glabrous, fairly smooth, greenish brown or greenish yellow; pedicel 0-0.5 mm long; young fruits ellipsoidal, with keeled locules; mature fruits depressed-globose, with rounded locules, $4-5$ by $5-6 \mathrm{~mm}$; exo- and mesocarp together c. $0.1 \mathrm{~mm}$ thick when dry, not separating from endocarp at dehiscence; endocarp c. $0.1 \mathrm{~mm}$ thick; columella persistent, 4 or 5 times longer than wide, $2-3$ by c. $0.5 \mathrm{~mm}$, triquetrous with parallel edges. Seeds 2 per locule, ecarunculate, roughly ovoid, nearly triangular in cross section, c. 3.5 by 2.5 by $2 \mathrm{~mm}$, hemitropous, smooth, light brown.

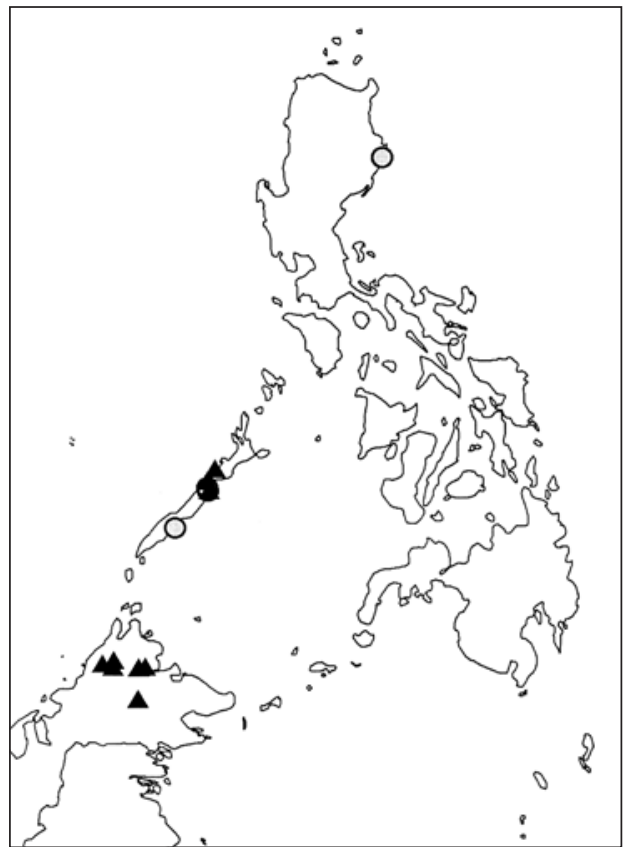

Map 1. Distribution of Phyllanthus balgooyi Petra Hoffm. \& A.J.M. Baker ( $\mathbf{\Delta})$ and P. lamprophyllus Müll.Arg. (O) in the Philippines and Sabah. 
Distribution - Sabah (Malaysian Borneo) and Palawan (Philippines).

Habitat \& Ecology - Generally growing as isolated individuals, restricted to ultramafic substrates in scrub or very stunted open forest (Proctor et al., 1997). In Sabah (Sandakan) in primary montane forest with Casuarina sumatrana and on hill ridges. Altitude in Sabah 600-1000 m, in Palawan 150-200 m. Phyllanthus lamprophyllus has been collected mainly along or in rivers, but also on limestone cliffs, in scrub, and in coconut plantations.

Conservation status - Six specimens from Palawan and eleven from Sabah are held in the herbaria at Kew and Leiden. The plant is said to be common by Ridsdale (SMHI 1584). It can be expected that more specimens are to be found in North American and South-East Asian herbaria. In Palawan the ultramafic mountains where this species occurs were previously sites of nickel and chromium mining activities. However, in the past five years these activities have been reduced and have actually ceased at many sites. We suggest to rate this species as NT (Near Threatened). For definitions of the IUCN categories see IUCN, 2001.

Etymology - This species is named in honour of the great expert on the Malesian flora M.M.J. van Balgooy who first suggested that this was a new taxon.

Paratypes - Sabah: Labuk \& Sugut, along Sungai Meliau, foot of Mt Tawai, Kokawa \& Hotta 94 (L); Ranau, Bukit Ampuan, SAN (Meijer) 20991 (L); Sandakan, Mt Melian near Kiabau Labuk, SAN (Meijer) 51578 (K); Labuk \& Sugut, Sungai Tongod, SAN (Aban et al.) 67639 (K, L); Ranau, Kampung Nalumad, SAN (Shea \& Ranau) 77278 (K, L); SAN (Shea \& Ranau) 77279 (K, L, SAN); Ranau, Bukit Ampuan, SAN (Madani) 89396 (K, L, SAN); Labuk \& Sugut, Meliau Range, F.R., SAN (Aban Gibot \& Dewol Sundaling) 91613 (K, L, SAN); Ranau, Mamut, SAN (Amin et al.) 121018 (K); Tongod, Gunung Tingkar, Wong 2203 (L, SAN); Sandakan, Sungai Meliau off Sungai Karamuak, Zainudin 4897 (K, L). - Palawan: Nagtabon hill, Madulid s.n. (L); Sitio Sabang, Cabayugan, PNH Field No. (Reynoso, Alvarez \& Fuentes) 11388 (K); Sitio Sabang, Cabayugan, Reynoso, Alvarez \& Fuentes s.n.(K); St Paul's Bay, Mt Bloomfield, Ridsdale SMHI 1584 (K, L); Puerto Princesa, Tagburus, Stone, Sagcal et al. PPI 254 (K, L); Paragua Island (Palawan), Vidal 3663 (K).

\section{ACKNOWLEDGEMENTS}

The authors thank the herbaria L and SAN for allowing us to study their collections. We are grateful to Lucy T. Smith (K) for drawing the plate, to Melanie Thomas (K) for help with the Latin diagnosis, to Justin Moat (K) for producing the map, and to Dr Mike Lock (K) for suggesting a Leguminosae taxon.

\section{REFERENCES}

Airy Shaw, H.K. 1976. New or noteworthy Australian Euphorbiaceae. Kew Bull. 31: 341-398. Airy Shaw, H.K. 1980a. The Euphorbiaceae of New Guinea. Kew Bull. Addit. Ser. 8: 1-243.

Airy Shaw, H.K. 1980b. A partial synopsis of the Euphorbiaceae-Platylobeae of Australia (excluding Phyllanthus, Euphorbia and Calycopeplus). Kew Bull. 35: 577-700.

Airy Shaw, H.K. 1982. The Euphorbiaceae of Central Malesia (Celebes, Moluccas, Lesser Sunda Islands). Kew Bull. 37: 1-40.

Airy Shaw, H.K. 1983. The Euphorbiaceae of the Philippines. Royal Botanic Gardens, Kew. 
Baker, A.J.M., J. Proctor, M.M.J. van Balgooy \& R.D. Reeves. 1992. Hyperaccumulation of nickel by the flora of the ultramafics of Palawan, Republic of the Philippines. In: A.J.M. Baker, J. Proctor \& R.D. Reeves (eds.), The vegetation of ultramafic (serpentine) soils: 291-304. Intercept Ltd., Andover, Hants, United Kingdom.

IUCN. 2001. IUCN Red List Categories. Prepared by the IUCN Species Survival Commission. IUCN, Gland, Switzerland, and Cambridge, United Kingdom.

Jaffré, T., R.R. Brooks, J. Lee \& R.D. Reeves. 1976. Sebertia acuminata: a hyperaccumulator of nickel from New Caledonia. Science 193: 579-580.

Merrill, E.D. 1912. Notes on Philippine Euphorbiaceae. Philipp. J. Sci., Bot. 7: 379-410.

Müller, J. 1866. Euphorbiaceae. In: A. de Candolle (ed.), Prodromus systematis naturalis regni vegetabilis 15, 2: 189-1286. Victor Masson, Paris.

Proctor, J., A.J.M. Baker, M.M.J. van Balgooy, L.A. Bruijnzeel, S.H. Jones \& D.A. Madulid. 2000b. Mount Bloomfield, Palawan, Philippines: forests on greywacke and serpentinized peridotite. Edinb. J. Bot.: 57: 121-139.

Proctor, J., A.J.M. Baker, M.M.J. van Balgooy, S.H. Jones, L.A. Bruijnzeel \& D.A. Madulid. 1997. Mount Bloomfield, Palawan, the Philippines: the scrub and Gymnostoma-woodland on ultramafic rocks. In: T. Jaffré, R.D. Reeves \& T. Becquer (eds.), Ecologie des millieux sur roches ultramafiques et sur sols métallifères: 123-131. Documents Scientifiques et Techniques, ORSTOM, Nouméa.

Proctor, J., A.J.M. Baker, L.A. Bruijnzeel, M.M.J. van Balgooy, G.M. Fairweather \& D.A. Madulid. 2000a. Foliar chemistry and leaf herbivory on Mount Bloomfield, Palawan, Philippines. Bot. J. Scotland 52: 79-89.

Robinson, C.B. 1909. Philippine Phyllanthinae. Philipp. J. Sci., Bot. 4: 71-105.

Webster, G.L. 1957. A monographic study of the West Indian species of Phyllanthus. J. Arnold Arbor. 38: 295-373.

Webster, G.L. \& H.K. Airy Shaw. 1971. A provisional synopsis of the New Guinea taxa of Phyllanthus (Euphorbiaceae). Kew Bull. 26: 85-109. 